\title{
Pedagogical leadership: an opportunity for teacher professional development in times of pandemic
}

\section{Liderazgo pedagógico: una oportunidad para el desarrollo profesional docente en periodo de pandemia}

\author{
ÁLVAREZ-CISTERNAS, Marisol del Carmen†**, TORRES-ORELLANA, Brunilda del Rosario and \\ MEDINA-GUAJARDO, Isabel Soledad
}

\author{
Universidad de Chile, Chile. \\ Universidad Andrés Bello, Chile.
}

\author{
ID $1^{\text {st }}$ Author: Marisol del Carmen, Álvarez-Cisternas / ORC ID: 0000-0002-1418-9524 \\ ID $1^{\text {st }}$ Co-author: Brunilda del Rosario, Torres-Orellana / ORC ID: 0000-0002-9810-462X \\ ID $2^{\text {nd }}$ Co-author: Isabel Soledad, Medina-Guajardo / ORC ID: 0000-0001-5034-7801
}

DOI: $10.35429 /$ JSEM.2021.22.8.9.15

Received January 15, 2021; Accepted June 30, 2021

\begin{abstract}
The objective of this article is to describe the pedagogical leadership exercised by teachers in times of pandemic, taking as a reference the Cadet Arturo Prat Chacón school in Chile and in what way this leadership can become an opportunity for teacher professional development. From the methodological point of view, the research is qualitative and descriptive, based on an intrinsic study of cases. The results allow us to establish in a situated way the qualities and attributes of pedagogical leadership, exercised by teachers in a pandemic period when they have to face the teaching-learning processes in a virtual way, and as despite their fears, challenges and uncertainties, They managed to overcome from a resilient pedagogical leadership, promoting collaborative work and co-teaching between teams. It can be concluded that the type of leadership displayed by the management team, facilitated the concurrence of efforts, facilitating collaborative work, co-planning and curricular prioritization, promoting autonomy and professional innovation, providing feedback and positive reinforcement among peers in a way constant, as confirmed by the teachers, who were able to stoically face adversity, safeguarding the quality of their classes.
\end{abstract}

Education, Pedagogical leadership, Professional development

\begin{abstract}
Resumen
El presente artículo, tiene por objetivo describir el liderazgo pedagógico ejercido por los docentes en tiempos de pandemia, tomando como referencia la escuela Cadete Arturo Prat Chacón de Chile y de qué manera este liderazgo pudo constituirse en una oportunidad para el desarrollo profesional docente. Desde lo metodológico, la investigación es de tipo cualitativa descriptiva, sustentada en un estudio intrínseco de casos. Los resultados, permiten establecer de manera situada las cualidades y atributos del liderazgo pedagógico, ejercido por los docentes en periodo de pandemia al tener que enfrentar los procesos de enseñanza-aprendizaje de manera virtual, y como a pesar de sus miedos, desafíos e incertidumbres, lograron sobreponerse desde un liderazgo pedagógico resiliente, promoviendo el trabajo colaborativo y la co-docencia entre los equipos. Se puede concluir que el tipo de liderazgo desplegado por el equipo de gestión, facilitó la concurrencia de esfuerzos, facilitando el trabajo colaborativo, de co-planeación y priorización curricular, promoviendo la autonomía e innovación profesional, otorgando retroalimentaciones y refuerzo positivo entre pares de manera constante, tal como lo confirman las docentes, quiénes fueron capaces de enfrentar de manera estoica la adversidad, resguardando la calidad de sus clases.
\end{abstract}

Educación, Liderazgo pedagógico, Desarrollo profesional

Citation: ÁLVAREZ-CISTERNAS, Marisol del Carmen, TORRES-ORELLANA, Brunilda del Rosario and MEDINAGUAJARDO, Isabel Soledad. Pedagogical leadership: an opportunity for teacher professional development in times of pandemic. Journal of Systems and Educational Management. 2021. 8-22:9-15.

\footnotetext{
* Correspondence to author (Email: marisol.alvarez.cis@gmail.com)

$\dagger$ Researcher contributing as first Author.
} 


\section{Introduction}

As of March 16, 2020, in the schools of Chile, the panorama of what they usually did changed. In effect, classes were suspended in all educational establishments, and on March 18 of this year, the State of Constitutional Exception of catastrophe began. In this way, the Cadet Arturo Prat Chacón school had to suddenly take on a set of challenges and tasks. It seems that the way the management team faced this situation, together with the type of leadership exercised by the management team and that of the teachers themselves in their classes, distributing tasks and functions, allowed them to advance as an educational community.

In this way, going from a face-to-face mode of classes to a totally virtual one, implied a great problem for the institution, since there were no previous studies or evidence on which to support its decisions and also because it did not have capacities installed in the school. However, it seems that the way the management team faced this process from the beginning and the empowerment of the teachers themselves, allowed them as a group to emancipate themselves.

However, the objective of this article is to describe the pedagogical leadership exercised by teachers in times of pandemic where their classes were all held in virtual mode, taking as a case the Cadet Arturo Prat Chacón school in Chile. In the same way, it is expected from the teachers' speeches, to delve into the characteristics of this leadership and how it can become an opportunity for the professional development of teachers.

\section{Development of the topic}

Studies by Sans-Martín (2016), Bolívar (2019), confirm the positive effects of the type of leadership exercised by management teams in educational organizations, particularly from the collaboration between members of the educational community, and as joint work among teachers, it usually has a positive impact on the pedagogical practice of the school. Similarly, Ahumada, González, Pino and Maureira (2017) emphasize the practice of distributive leadership among teachers, and the timely assignment of roles and tasks, thereby promoting school improvement.
Distributive leadership is understood more as a practice than as a style (Ahumada, González \& Pino, 2016), since it requires a process of changes in beliefs and delegation of tasks in the levels that make up the educational community. What is confirmed by Weinstein (2016); the social character that occurs in the multiple interactions, is relevant for the improvement of educational centers and the various levels that comprise it. For their part, Montecinos, Aravena and Tagle (2016), refer to the need for a greater empirical deepening, regarding the leadership exercised in educational institutions, particularly in the classroom, in such a way as to achieve the required status of the practice school.

Referring to pedagogical leadership, is to convene a set of practices that are carried out at the school level, including the classroom, exercised by educational leaders and teachers as pedagogical leaders within their classroom, this with the purpose of promoting among their students, high levels of significant and quality learning. In this way, as expressed by Gajardo and Ulloa (2016), pedagogical leadership, in order to be effective, requires practices that make it possible to establish shared purposes and goals, promoting the professional development of teachers, generating conditions at the level of the schools that become true catalysts for a culture of collaboration.

As expressed by Gajardo et al. (2016), there are two approaches to significant pedagogical leadership, with different traditions. In this way, Bush and Glover (2014) refer it to the theories of instructional leadership (instructional leadeship) of North American origin, focusing on the behavior of teachers and their relationship with activities that directly affect the quality of teaching. While, from English approaches, the notion of pedagogical leadership centered on learning (learningcentered leadership) is assumed, emphasizing the need to incorporate a variety of leadership actions that preferably promote quality and meaningful learning for students. 
Rhodes and Brundrett (2009), refer to the criticisms that arise to instructional leadership, since it is articulated more to teaching than to learning. Preferably relieving the figure of the director as a center of expertise, power and authority, tending to ignore other leaders, such as teachers and other levels that make up the educational community. For its part, the concept of leadership for learning (learning-centered leadership) represents a mix between early conceptualizations of leadership, that is, instructional and distributive leadership (Hallinger, 2010; Hallinger and Heck, 2010). According to Hallinger (2010), both models emphasize that the educational director's focus should be:

- $\quad$ Propose and implement shared purposes in the school.

- $\quad$ Promote a climate of high expectations and a school culture focused on continuous improvement of both teaching and learning.

- Create incentive structures in the school, for staff and students.

- $\quad$ Generate and facilitate the implementation of a wide range of activities aimed at stimulation and intellectual development for staff.

- Make their actions visible, becoming a benchmark for the promotion of values in the establishment and in line with the institutional educational project.

According to Hallinger (2010), it is possible to appreciate in a school, a direct pedagogical leadership, which requires, on the one hand, that efforts be focused on promoting the quality of teaching practice, that is, it considers the quality of the curriculum, the teaching and evaluation, as well as teacher professional development, which involves not only the figure of the principal but that of the teacher himself as a pedagogical leader in his classroom, committed to the continuous improvement of his teaching practice.
While indirect pedagogical leadership focuses all institutional and personal efforts to create adequate conditions for good teaching and learning, ensuring that decisions at the institutional and personal management level support and enhance both teaching and learning, therefore what a harmonious combination of both pedagogical leaderships could promote better results in educational institutions.

Moral, Amores and Ritacco (2016), García (2017), García-Gárnica (2016), Rodríguez, Ordóñez and López (2020), confirm the influence of the management team on the pedagogical leadership exercised by teachers in the classroom. In effect, organizational decisions must be oriented towards enhancing the quality of the teaching-learning processes.

From the contributions of Gómez and Medina (2015), the need in schools is revealed for leaderships that integrate management, human and technical competencies in the design and implementation of teaching-learning processes, creating environments that promote the comprehensive improvement of the educational community, with great commitment to personal and professional performance, for which transformational and distributive leadership must be consolidated, promoting empathy, teamwork, delegation of functions, active listening, the involvement of the community, the analysis of cases and the promotion of the institutional culture.

González, Gento and Orden (2016), endorse the need that the exercise of leadership within an educational institution must be eminently pedagogical. In this way, the leader profile is characterized by the presence of a series of dimensions, including the formative.

According to Bolívar (2015), the teacher manifests pedagogical leadership, when he is able to influence not only his students, but also in communion with his peers, it is a collaborative process, where collegiate capacities are mobilized, in a context of co-teaching. This situation provides structures that make it possible for teachers to develop their professional capital, individually and as teams of professionals (Hargreaves and Fullan, 2014). 
In this way, in the Arturo Prat Chacón Cadet School, the pedagogical leadership exercised by its teachers in virtual mode, turned out to be one of the catalytic factors, to develop management and organization skills within the school and classroom, because despite Due to uncertainty and fear, teachers were able to innovate, work democratically and learn together with their peers (Bolívar, 2014; Contreras, 2016). Indeed, when teachers manage their pedagogical processes with the objective of achieving and guaranteeing quality learning for all students, we are facing a teacher who leads their pedagogical processes regardless of the teaching modality, based on a culture of equity, inclusion, participation and innovation, which promotes continuous improvement, as stated by Contreras (2016).

\section{Methodology}

The research is assumed from an intrinsic study of cases, following the postulate of Sandín (2003), with the purpose of investigating and understanding the concepts and networks of meanings that teachers perceive regarding pedagogical leadership experienced in virtual mode and how this has influenced in their professional teaching development. The sample was made up of six teachers who voluntarily wanted to participate, sending three questions to their personal emails, they had a week to respond and send their contributions through the same medium.

From the questions asked, we have:

1. In this period of pandemic and when facing the development of your classes in virtual mode, what have been your fears, challenges and benefits that it has meant for you as a teacher and pedagogical leader?

2. How do you characterize the leadership that you have exercised in the planning and development of your classes?

3. In what way could the pedagogical leadership that you have exercised have benefited your teaching professional development?
Later, these same teachers were summoned to a meeting, using the zoom meeting platform. The qualitative information was transcribed in textual form, the analysis was carried out from an inductive approach, through the constant method of comparison Glaser and Strauss (1967), using the qualitative analysis software Atlas $\mathrm{T}$, following the proposal of Huberman and Miles (1994), safeguarding the criteria of credibility, transferability and confirmability.

\section{Results and Discussion}

From the qualitative analysis carried out, it was possible to deepen the knowledge and understanding of the interviewed teachers. Conforming four categories of descriptive analysis and 49 units of meaning relevant to the teachers interviewed, as illustrated in table I.

\begin{tabular}{|l|r|}
\multicolumn{1}{c}{$\begin{array}{c}\text { Descriptive } \\
\text { Categories }\end{array}$} & $\begin{array}{c}\text { Number of units of } \\
\text { meanings }\end{array}$ \\
\hline Role assumed & 12 \\
\hline Fears & 14 \\
\hline Challenges & 15 \\
\hline Benefits & 8 \\
\hline
\end{tabular}

Table 1 Categorization and units of meaning relevant to teachers

Source: Own elaboration, (2021)

With the purpose of looking for similarities of content, structure and theory. From the descriptive categories, two metacategories were formed, as illustrated in table 2.

\begin{tabular}{|l|l|l|}
\hline \multicolumn{1}{|c|}{ Meta-categories } & \multicolumn{1}{c|}{ Coding } & \multicolumn{1}{c|}{ Definition } \\
\hline $\begin{array}{l}\text { Pedagogical } \\
\text { leadership } \\
\text { exercised. }\end{array}$ & LP & $\begin{array}{l}\text { Description of } \\
\text { pedagogical } \\
\text { leadership exercised } \\
\text { in classes. }\end{array}$ \\
\hline $\begin{array}{l}\text { Contributions to } \\
\text { Teacher } \\
\text { Professional } \\
\text { Development. }\end{array}$ & CDPD & $\begin{array}{l}\text { Contributions to } \\
\text { Teacher Professional } \\
\text { Development. }\end{array}$ \\
\hline
\end{tabular}

Table 2 Meta-categories, codes and definition Source: Own elaboration (2021)

From the meta-categories, which considers two qualitative domains, the teaching opinions were gathered, as an illustration in table 3 some of the opinions are transcribed. 


\begin{tabular}{|c|c|c|c|c|}
\hline $\begin{array}{c}\text { Meta- } \\
\text { categories / } \\
\text { Domains (D) }\end{array}$ & Role & Fears & Challenges & Profits \\
\hline $\begin{array}{l}\text { Pedagogical } \\
\text { leadership } \\
\text { exercised. }\end{array}$ & $\begin{array}{l}\text { "Innovative, } \\
\text { patient and } \\
\text { trustworthy, } \\
\text { the classes take } \\
\text { place in a } \\
\text { pleasant } \\
\text { environment, } \\
\text { of tenderness } \\
\text { and kindness of } \\
\text { the teacher } \\
\text { towards her } \\
\text { students and } \\
\text { vice versa; } \\
\text { classes } \\
\text { prepared with } \\
\text { dedication to } \\
\text { achieve } \\
\text { learning and } \\
\text { participation to } \\
\text { develop their } \\
\text { activities; } \\
\text { classes that } \\
\text { present their } \\
\text { beginning, } \\
\text { development } \\
\text { and closure and } \\
\text { provide } \\
\text { feedback to the } \\
\text { children at the } \\
\text { same time. " } \\
\text { "Participative } \\
\text { and interactive. } \\
\text { In addition to } \\
\text { assuming this } \\
\text { challenge, } \\
\text { interns, } \\
\text { intermediate } \\
\text { level students } \\
\text { were } \\
\text { incorporated. I } \\
\text { have been } \\
\text { developing } \\
\text { dynamic } \\
\text { classes, } \\
\text { through } \\
\text { different such } \\
\text { resources such } \\
\text { as interactive } \\
\text { power points, } \\
\text { incorporating } \\
\text { sounds, online } \\
\text { applications } \\
\text { (quiziz or } \\
\text { worwall). } \\
\text { I have allowed } \\
\text { the interaction } \\
\text { of students in } \\
\text { practice and for } \\
\text { the next } \\
\text { meeting, I will } \\
\text { give space for } \\
\text { the realization } \\
\text { of activity by } \\
\text { the students in } \\
\text { practice. " } \\
\text { "The role that } \\
\text { is assumed in } \\
\text { these } \\
\text { circumstances } \\
\text { is a role of } \\
\text { protection, of } \\
\text { care, where it is } \\
\text { about } \\
\text { managing the } \\
\text { variables to } \\
\text { protect the } \\
\text { health and } \\
\text { well-being of } \\
\text { all. It is innate } \\
\text { and natural, we } \\
\text { protect } \\
\text { ourselves, } \\
\text { especially the } \\
\text { most } \\
\text { vulnerable, } \\
\text { children and } \\
\text { the elderly. " }\end{array}$ & $\begin{array}{l}\text { "My fears } \\
\text { have been } \\
\text { being } \\
\text { criticized by } \\
\text { parents in } \\
\text { virtual } \\
\text { classes, } \\
\text { spending } \\
\text { more time at } \\
\text { work than } \\
\text { usual, } \\
\text { spending } \\
\text { more time } \\
\text { sitting in a } \\
\text { chair in front } \\
\text { of the } \\
\text { computer and } \\
\text { over- } \\
\text { stimulating } \\
\text { vision." } \\
\text { "My fear in } \\
\text { online classes } \\
\text { is being a } \\
\text { meme, or } \\
\text { feeling that } \\
\text { students are } \\
\text { not motivated } \\
\text { to participate } \\
\text { in class. The } \\
\text { challenge is } \\
\text { always to be } \\
\text { testing new } \\
\text { strategies and } \\
\text { to improve } \\
\text { where we } \\
\text { can. And the } \\
\text { biggest } \\
\text { benefit is that } \\
\text { many } \\
\text { students took } \\
\text { online classes } \\
\text { as a learning } \\
\text { opportunity. } \\
\text { n }\end{array}$ & $\begin{array}{l}\text { "The } \\
\text { challenges are } \\
\text { directly } \\
\text { related to the } \\
\text { fears since } \\
\text { overcoming } \\
\text { these fears } \\
\text { implies } \\
\text { entering a new } \\
\text { learning } \\
\text { environment, } \\
\text { where most of } \\
\text { the learning } \\
\text { happens or } \\
\text { should happen } \\
\text { in a virtual } \\
\text { context, } \\
\text { without direct } \\
\text { interaction, } \\
\text { which means } \\
\text { working with } \\
\text { different } \\
\text { strategies, use } \\
\text { creativity, } \\
\text { establish new } \\
\text { habits and } \\
\text { protocols and } \\
\text { redesign the } \\
\text { education } \\
\text { model. " }\end{array}$ & $\begin{array}{l}\text { "My benefits } \\
\text { of conducting } \\
\text { personalized } \\
\text { classes for } \\
\text { groups of } \\
\text { students, of } \\
\text { supporting } \\
\text { and helping } \\
\text { parents to } \\
\text { carry out the } \\
\text { tasks and } \\
\text { strengthen } \\
\text { skills in the } \\
\text { students." } \\
\text { "Being } \\
\text { inserted in a } \\
\text { new } \\
\text { educational } \\
\text { context, it has } \\
\text { clearly } \\
\text { enriched my } \\
\text { teaching } \\
\text { professional } \\
\text { development, } \\
\text { I have looked } \\
\text { for resources } \\
\text { and } \\
\text { applications } \\
\text { that can } \\
\text { support my } \\
\text { virtual } \\
\text { meeting and } \\
\text { in this way } \\
\text { enrich the } \\
\text { learning } \\
\text { experience } \\
\text { with my } \\
\text { students." }\end{array}$ \\
\hline $\begin{array}{l}\text { Contributions } \\
\text { to Teacher } \\
\text { Professional } \\
\text { Development. }\end{array}$ & \multicolumn{4}{|c|}{$\begin{array}{l}\text { "This has been a learning period for everyone and in all circumstances. } \\
\text { Undoubtedly, the acquired experience will last as part of the history of } \\
\text { our country and its institutions, and it has allowed all education } \\
\text { professionals to look away a little to observe our pedagogical work from } \\
\text { another perspective. What is derived from this look are projections } \\
\text { towards the future and questions, which makes possible an accumulation } \\
\text { of specialized opinions analyzing the present and future of education in } \\
\text { Chile. Without a doubt, that is professional growth and development." }\end{array}$} \\
\hline
\end{tabular}

Table 3 Meta-categories and qualitative domains Source: Own elaboration (2021)
Additionally, figure 1, the semantic network formed from the four descriptive categories that arise from the analysis carried out is presented.

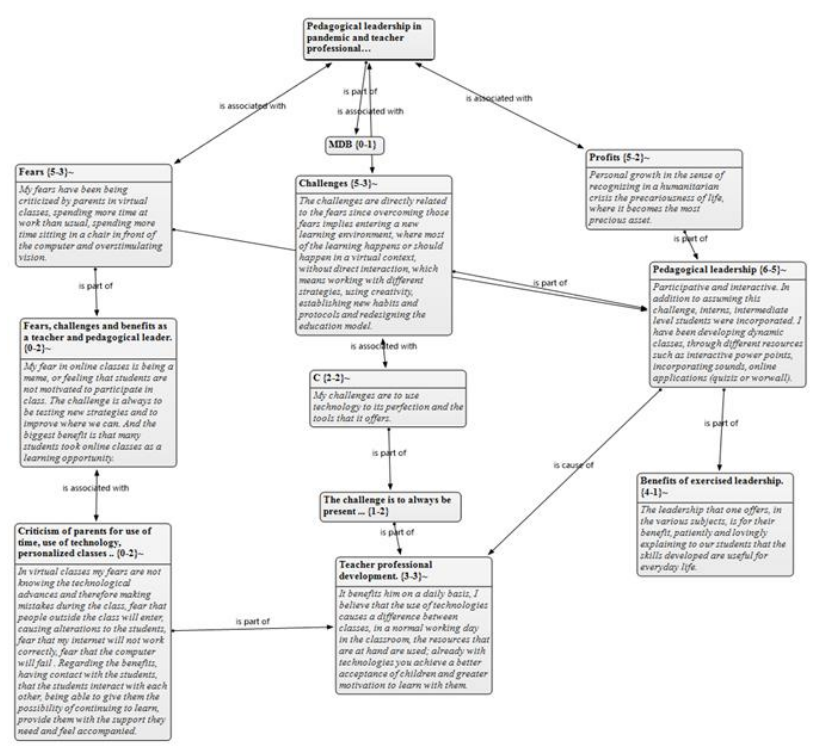

Figure 1 Semantic network of categories Source: Own elaboration (2021)

From the results obtained, the findings of Moral et al. (2016), García (2017), GarcíaGárnica (2016) and Rodríguez et al. (2020), in that the leadership exercised by teachers in the school has been influenced by the type of leadership displayed by the management team. This highlight and confirms what was formulated by Bolívar (2019) and Contreras (2016), since teachers were able to innovate in the face of a virtual modality, making use of tics and other resources, preparing didactic material, working in co-teaching, prioritizing curricularly, thereby deploying organizational learning, supported by innovation, collaboration and resilience.

The findings of Gómez and Medina (2015) are confirmed, regarding the need to create environments that promote continuous and comprehensive improvement in the educational community, moving towards the consolidation of transformational and distributive leaderships. The emphasis on pedagogical leadership exercised by teachers according to the evidence, emphasizes the pedagogical and formative in their relationship with students, which agrees with the contributions of González, Gento and Orden (2016). 
In the same way, based on the evidences of the present study, it is possible to confirm the proposals of Hallinger (2010), in the sense of coexisting direct and indirect pedagogical leadership, which in a primordial harmony allowed teachers to face their classes resiliently.

\section{Conclusions}

Undoubtedly, the study has confirmed that the teachers of the Cadete Arturo Prat Chacón school, despite the pandemic, made a qualitative leap in their professional teaching development, facing their fears, uncertainties and challenges. It could be said that teachers were able to overcome an extreme situation, such as the pandemic, and be confronted from one day to the next with a totally virtualized teaching-learning modality, which in all cases meant updating and innovating their way of teaching, learning and incorporating the use of virtual tools in their classes, training in virtual environments, working collaboratively, contributing all of the above to their own training and professional development. The coexistence of pedagogical leadership promoted by the establishment authorities is evidenced, facilitating the concurrence of efforts, collaborative work, promoting autonomy and professional innovation. In the same way, from the teacher himself we could refer to a new category of analysis, which originally emerges in this study, which is a resilient pedagogical leadership, which requires further investigation and deepening in subsequent studies.

\section{References}

Ahumada, L., González, A. y Pino, M. (2016), Redes de mejoramiento escolar: ¿por qué son importantes y cómo las apoyamos?. Documento de trabajo No. 1, Santiago de Chile, Líderes Educativos-Centro de Liderazgo para la Mejora Escolar.

Ahumada, L., González, A., Pino, M. Maureira, O. (2017), Liderazgo distribuido en establecimientos educacionales: recurso clave para el mejoramiento escolar. Informe Técnico $N^{\circ}$ 7, Santiago de Chile, Líderes EducativosCentro de Liderazgo para la Mejora Escolar.

Bolívar, A. (2019), Una dirección escolar con capacidad de liderazgo pedagógico, Madrid, La Muralla.
Bolívar, A. (2014). Liderazgo educativo y desarrollo profesional docente: Una revision internacional. En J. Ulloa, \& S. Rodríguez (Eds.), Liderazgo escolar y desarrollo profesional de docentes: Aportes para la mejora de la escuela. Universidad de Concepción (Chile) (pp. 61-103). Santiago de Chile: RIL editores. Recovered from: https://www.rileditores.com/catlogoril02/i3c06ywm35/Liderazgo-escolarydesarrollo-profesional-de-docentes-aportespara-la-mejora-de-la-escuela

Bolívar, A. (2015). Un liderazgo pedagógico en una comunidad que aprende. Padres y Maestros, 361, 23-27. doi:10.14422/pymi361y2015.004

Bush, T., y Glover, D. (2014). School leadership models: What do we know ? School Leadership \& Management, 34(5), 553-571.

Contreras, T. (2016). Liderazgo pedagógico, liderazgo docente y su papel en la mejora de la escuela: una aproximación teórica. Propósitos y Representaciones, 4(2), 231-284.

Domínguez, M. C., Leví, G., Medina, A. y Ramos, E. (2017). Las competencias docentes: Diagnóstico y actividades innovadoras para su desarrollo en un modelo de educación a distancia. REDU. Revista de Docencia Universitaria, 12(1), 239-267.

García, I. (2017). Innovación educativa desde el liderazgo distribuido: Estudio de caso escuela pública Española. Propósitos y Representaciones, 5(1), 205-273.

García-Garnica, M. (2016). La relevancia del liderazgo pedagógico para la mejora y la calidad de la educación. Revista Internacional de Didáctica y Organización Educativa 1(2), 4-20.

Garcia, J., Ulloa, J (2016). Liderazgo Pedagógico, Conceptos y Tensiones. Nota Técnica $\mathrm{N}^{\circ} 6$, LIDERES EDUCATIVOS, Centro de Liderazgo para la Mejora Escolar: Universidad de Concepción, Chile.

Gómez, R. y Medina, A. (2015). El liderazgo pedagógico: Competencias necesarias para desarrollar un programa de mejora en un centro de educación secundaria. Perspectiva Educacional, 53(1), 91-113. 
González, R., Gento, S. y Orden, V. (2016). Importancia de la dimensión formativa de los líderes pedagógicos. Revista Iberoamericana de Educación, (70), 131-144.

Recovered

from:

http://hdl.handle.net/10481/45033

Glaser B, Strauss A. (1967). The discovery of grounded theory: Strategies for qualitative research. New York: Aldine Publishing Company; p.101-15.

Hallinger, P. (2010). Gateways to leading learning. Leading educational change. APCLC Monograph Series (Vol. 1). http://doi.org/10.1017/CBO9781107415324.00 4

Hallinger, P., y Heck, R. H. (2010). Leadership for learning: Does collaborative leadership make a difference in school improvement? Educational Management Administration \& Leadership, 38(4), 654-678.

Hargreaves, A., \& Fullan, M. (2014). Capital Profesional. Madrid: Morata.

Huberman A, Miles M. (1994). Data management and analysis methods. En: Denzin $\mathrm{N}$, Lincon Y, editores. Handbook of Qualitative Research. Thousand Oaks, California: Editorial Sage; p. 428-44.

Montecinos, C., Aravena, F. y Tagle, R. (2016), Liderazgo escolar en los distintos niveles del sistema: notas técnicas para orientar sus acciones, Santiago de Chile, Líderes Educativos-Centro de Liderazgo para la Mejora Escolar/Pontificia Universidad Católica de Valparaíso

Moral, C., Amores, F., \& Ritacco, M. (2016). Liderazgo distribuido y capacidad de mejora en centros de educación secundaria. Estudios sobre educación, 30, 115-143.

Rhodes, C., y Brundrett, M. (2009). Leadership development and school improvement. Educational Review, 61(4), 361-374.

Rodríguez, M., Ordóñez, R., \& López, A. (2020). La dirección escolar: Liderazgo pedagógico y mejora escolar. Revista de Investigación Educativa, 38(1), 275-292.
Sandin, M.P. (2003). Investigación Cualitativa en Educación. Fundamentos y Tradiciones. Madrid. Mc Graw and Hill Interamericana de España (pp.258).

Sans-Martín, A., Guardia, J. y Triadó-Ivern, X. (2016), "El liderazgo educativo en Europa: una aproximación transcultural", Revista de Educación, núm. 371, pp. 83-99.

Weinstein, J. (2016), Liderazgo educativo en la escuela. Nueve miradas, Santiago de Chile, Ediciones Universidad Diego Portales. 